\title{
Terorisme Di Mesir: Analisis Terhadap Narasi Terorisme Pasca Arab Spring
}

\author{
Reza Bakhtiar Ramadhan \\ Pascasarjana UIN Sunan Kalijaga Yogyakarta \\ manmanna93@gmail.com \\ Irham Shofwan \\ Pascasarjana UIN Sunan Kalijaga Yogyakarta \\ irhamshofwan@gmail.com
}

\section{ABSTRACT}

Since the start of Arab Spring, the Middle East has witnessed the escalation of terrorism acts. Egypt even entered the emergency zone of terrorism after the fall of Muhammad Mursi from the presidency. Various groups of terror emerged in Egypt, among them is Anshar Bayt AI Maqdis who later joined ISIS and renamed Wilayat Sinai. This paper aims to analyze the transformation of terrorist groups by using instrumental and organizational theory. The finding of this research are that the ABM group is a transformation of pre-existing terror groups. It develop the organisation through delivering benefits, affiliations, competition, recruitment of members who use religious doctrine and take advantage of the economic and political conditions in the Sinai region.

Keywords: terrorism, Arab Spring, Egypt, Muslim Brotherhood, Anshar Bait Al Maqdis

\section{ABSTRAK}

Sejak dimulainya Arab Spring, Timur Tengah menyaksikan terjadinya eskalasi aksiaksi terorisme di Timur Tengah. Mesir bahkan memasuki zona darurat terorisme pasca lengsernya Muhammad Mursi dari kursi kepresidenan. Berbagai kelompok 
teror bermunculan di Mesir, di antaranya Anshar Bayt Al Maqdis yang kemudian bergabung dengan ISIS dan berganti nama menjadi Wilayat Sinai. Tulisan ini bertujuan untuk menganalisis transformasi kelompok-kelompok teroris tersebut dengan menggunakan teori instrumental dan organisasional. Temuan penelitian ini adalah bahwa kelompok ABM merupakan transformasi dari kelompok teror yang sudah ada sebelumnya dan bisa berkembang berkat proses delivering benefits, afiliasi, kompetisi, rekrutmen anggota yang menggunakan doktrin agama dan memanfaatkan kondisi ekonomi dan politik di kawasan Sinai.

Kata kunci: terorisme, Arab Spring, Mesir, Ikhwan Al Muslimin , Anshar Bait Al Maqdis

\section{Pendahuluan}

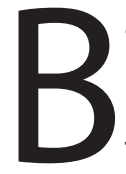
adai Arab Spring menyisakan banyak pekerjaan rumah bagi negaranegara Timur Tengah berupa berubahnya konstelasi kehidupan bernegara, terutama dalam bidang politik, di kawasan itu (BHP UMY, 2016). Hal senada disampaikan Prof. Dr. Muhammad Al Mestiri yang menyatakan bahwa terdapat permasalahan baru yang harus dihadapi negara-negara yang mengalami Arab Spring yakni dengan munculnya pergerakan-pergerakan Islam di berbagai negara yang berpenduduk mayoritas Muslim, (BHP UMY, 2016). Melalui protes massal terhadap rezim berkuasa, Tunisia dan Mesir berhasil melakukan revolusi politik dan berhasil menumbangkan rezim yang telah berkuasa lebih dari 30 tahun. Aksi protes ini, yang kemudian diberi istilah 'Arab Spring' kemudian menjalar ke Libya yang mengakibatkan tumbangnya rezim Qaddafi dan bahkan tewasnya Sang Presiden dalam aksi terorisme kelompok-kelompok militan. Aksi protes serupa pun terjadi di Suriah dan Yaman, yang kemudian meluas menjadi medan perang saudara hingga sekarang. Di negara-negara monarkhi Teluk, seperti Bahrain, Saudi, dan Kuwait, aksiaksi demo juga terjadi namun dapat diredam oleh rezim yang berkuasa.

Aksi-aksi demo di negara-negara Timur Tengah pada era Arab Spring pada dasarnya menghendaki perubahan politik di masing-masing negara. Meskipun efeknya berbeda-beda di tiap negara, secara umum, Arab Spring mendorong munculnya gerakan-gerakan Islam yang menghendaki perubahan secara radikal. Di Tunisia, muncul kelompok Al-Mutabayi'un 'ala Al-Maut, Jundu Asad ben Al-Furat, dan Kataib 'Aqabah ben Nafi' (Noon Post, 2014). Di Aljazair ada Al-Qaeda Maroko, Harakah At-Tauhid wa Al-Jihad dari Mali, dan Al-Murabithun (Aljazeera, 2017). Sementara di 


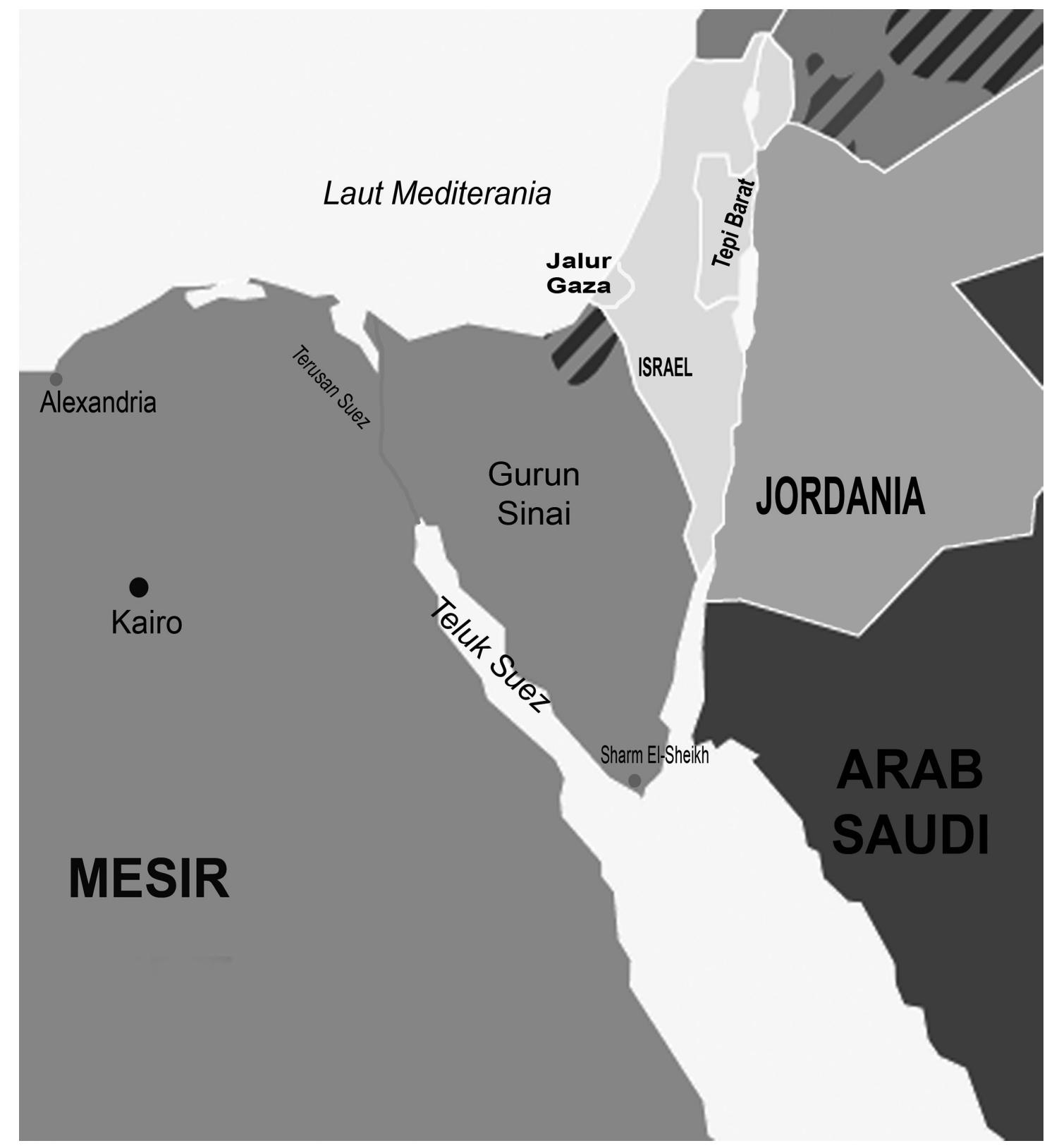

Yaman ada Al-Qaeda Yaman (AQAP) dan lembaga pendidikannya Dar Al-Hadis di kota Damaj (As-Shawwani, 2013). Dan di Libya, Anshar As-Syari'ah adalah kelompok yang paling berpengaruh (Sky News Arabia, 2015).

Kemunculan organisasi Islam radikal juga terjadi di Mesir. Momen penggulingan Husni Mubarak boleh dikatakan sebagai momen revolusi rakyat Mesir karena pada saat itu aksi-aksi protes massa sedemikian besar menuntut mundurnya Mubarak yang telah berkuasa 30 tahun. Meskipun rezim melakukan aksi-aksi kekerasan namun gelombang kehendak rakyat tidak bisa lagi dibendung sehigga Mubarak pun lengser pada 11 Februari 2011. Setelah itu terjadilah proses-proses demokrasi yang akhirnya menghantarkan Muhammad Mursi dari Ikhwan Al Muslimin (IM) ke kursi 
kepresidenan. Namun, dinamika politik Mesir kemudian berujung kepada aksi-aksi demo yang menginginkan mundurnya Mursi. Aksi-aksi ini kemudian dimanfaatkan militer untuk mengkudeta Mursi pada tahun 2013.

Situasi inilah yang memicu berbagai serangan dan aksi teror dari kelompokkelompok yang diklaim sebagai dari pendukung Mursi, berupa pengeboman dan penyerangan brutal terhadap kantor-kantor pemerintahan dan tokoh-tokoh pemerintah. Sasaran serangan kemudian juga meluas ke beberapa gereja. Aksi pengeboman yang terbaru adalah penembakan terhadap para jamaah sholat Jumat di Masjid Al- Raudhah di Kota Birel-Abd, 50 km barat Kota El-Arish, Sinai Utara, 24 November 2017. Namun klaim tersebut juga diragukan karena pertama, tidak ada pengakuan dari pihak IM dan kedua, banyak penelitian yang melaporkan bahwa serangan-serangan tersebut berasal dari dua faksi, yaitu kelompok-kelompok teror di wilayah Sinai Utara, dan kelompok-kelompok teror lain non-Sinai yang ada di dalam negeri (Global Security, 2017).

Hal ini menimbulkan beberapa pertanyaan. Pertama, siapa dan dari pihak manakah kelompok-kelompok tersebut? Kedua, apa motivasi dan tujuan mereka melakukan serangan-serangan teror di Mesir? Ketiga, mengapa mereka meningkatkan serangan-serangan teror semenjak dilengserkannya Mursi? Keempat, mengapa mereka mengarahkan serangan kepada pemerintah dan gereja?

Tulisan ini hendak mengkaji narasi aksi-aksi terorisme di Mesir pasca lengsernya Mursi dari jabatan presiden untuk melihat transformasi kelompok-kelompok terorisme di negara itu. Kajian diuraikan dengan berdasarkan rumusan-rumusan di atas, dan dengan teori organisasional dan instrumental sebagai perangkat analisisnya.

\section{Landasan Teori}

\section{A. Terorisme}

Definisi terorisme menurut Pasal 6 Undang-Undang No.15 Tahun 2003 tentang Pemberantasan Tindak Pidana Terorisme adalah :

"Setiap orang yang dengan sengaja menggunakan kekerasan atau ancaman kekerasan menimbulkan suasana teror atau rasa takut terhadap orang secara meluas atau menimbulkan korban yang bersifat masal, dengan cara merampas kemerdekaan atau hilangnya nyawa dan harta benda orang lain, atau 
mengakibatkan kerusakan atau kehancuran terhadap obyek-obyek vital yang strategis atau lingkungan hidup atau fasilitas publik atau fasilitas internasional"

Pengertian teror itu sendiri menurut Kamus Besar Bahasa Indonesia (KBBI) adalah "Usaha untuk menciptakan ketakutan, kengerian, dan kekejaman oleh seseorang atau golongan tertentu." Namun demikian, penggunaan teror tidak otomatis merupakan "terorisme" karena "teror" dapat dilakukan untuk tujuan-tujuan kriminal dan personal (Salenda, 2009). Sehingga tidak semua tindak kekerasan dapat dikategorikan sebagai aksi terorisme. Aksi-aksi terorisme dilakukan dalam bentuk intimidasi pemaksaan secara sistematis dan disengaja, dan ditujukan untuk efek politis.

Antara aksi kriminal dan aksi teroris dibedakan oleh alasan dilakukannya aksi tersebut, pelakunya, dan korbannya. Aksi kejahatan biasa umumnya dilakukan untuk satu tujuan terbatas tertentu, misalnya, ingin merampok uang korbannya. Sementara tujuan yang ingin dicapai aksi terorisme bersifat jangka panjang dan berkembang. Dari sisi pelaku, organisasi kriminal umumnya beranggota terbatas; sementara organisasi teroris bersifat rahasia dan perekrutan anggota organisasi tersebut dilakukan sebanyak mungkin. Dan terakhir, dari sisi target, aksi kriminal memiliki target khusus sesuai tujuannya (seperti, memilih orang yang diduga punya uang untuk dirampok). Sebaliknya, aksi-aksi terorisme seringkali bersifat acak; para korban umumnya adalah orang yang tak terkait dengan tujuan besar organisasi terori tersebut (Conte, 2010).

Kesimpulannya, terorisme memang merupakan tindakan atau ancaman yang dapat mengganggu keamanan banyak orang, tapi ia terencana, ada tujuan politis yang melekat, dan dianggapilegal oleh kebijakan sebuah negara maupun adat umum. Dari beberapa pendapat di atas terorisme dapat didefinisikan sebagai penggunaan kekerasan yang ditujukan untuk mengubah kebijakan pemerintah dalam suatu isu (atau beberapa isu) tetapi kekerasan tersebut diarahkan kepada orang-orang yang sebenarnya tidak terhubung kepada kebijakan tersebut (Ozdamar, 2008:94).

\section{B. Pendekatan Instrumental dan Pendekatan Organisasional}

Pendekatan instrumental (instrumental approaches) memandang bahwa aksi teror dilakukan secara disengaja oleh aktor politik. Dengan kata lain, terorisme merupakan alat (tool) yang digunakan oleh pelakunya untuk mengakhiri stabilitas politik. Teori ini mengandung acuan bahwa aksi-aksi teror dilakukan berdasarkan: 
1. Adanya perhitungan cost and benefit.

2. Tidak hanya menarget objek, namun juga menarget kesuksesan aksi.

3. Aksi mereka adalah rasional dan memutuskan dilakukannya aksi dengan bekerjasama dan berinteraksi dengan aktor lain.

4. Perubahan konstelasi politik menjadi tanda keberhasilan aksi (Ozdamar, 2008:91-92).

Untuk membaca perhitungan dan rasionalitas aksi-aksi mereka, penulis menggunakan pendekatan organisasional (organizational approach). Teori ini dalam kajian terorisme mengandung pengertian bahwa terorisme hari ini berbasis kepada sistem organisasi dan tujuan utamanya adalah keberlanjutan misi (survival) (Ozdamar, 2008:93). Bentuk eksistensi dan sistem kerja dengan basis organisasi menjadikan terorisme seperti sebuah perusahaan (firma). Seluruh aktivitas kerjanya mirip perusahaan dengan adanya perhitungan terhadap untung-rugi dan loyalitas di balik setiap aksi-aksinya.

Pengertian tersebut kemudian menyajikan pembacaan bahwa narasi dalam aksi-aksi terorisme tidak lepas dari:

1. Adanya proses delivering benefits dari pemimpin kepada para anggotanya, untuk menjaga loyalitas dan keutuhan organisasi. Maka munculnya kelompok yang menyempal atau berpindah afiliasi kepada kelompok lain, bisa dipahami berdasarkan timpangnya proses delivering benefits itu.

2. Adanya sebuah manuver kompetisi. Hal inilah yang menyebabkan munculnya klaim dari berbagai kelompok teror untuk satu aksi.

3. Proses pencarian anggota atau afiliasi. Aksi-aksi teror salah satunya ditujukan untuk meraih perhatian orang-orang yang sesungguhnya memiliki kecenderungan radikal untuk bergabung dengan organisasi sang aktor.

4. Proses komunikasi dua jalur. Suatu aksi teror juga merupakan pemanggilan, sehingga akan disusul dengan aksi-aksi teror dari kelompok lainnya. Ini jalur komunikasi pertama. Setelah itu disusul klaim yang biasanya mengutipsertakan bahasa-bahasa agama. Pengutipan ini sesungguhnya adalah kata kunci untuk berkomunikasi secara tidak langsung dengan orang-orang yang berkecenderungan radikal, agar mereka mendukung, atau bahkan meniru, baik dalam bentuk organisasi maupun solo (Ione wolf terrorist). Ini jalur komunikasi kedua. 


\section{Periodisasi Terorisme di Mesir}

Terorisme dalam konteks Mesir terbagi menjadi beberapa periode, termasuk di dalamnya periode gerakan Islamisme. Sebelum Perang Dunia I, Mesir adalah bagian dari Kekhalifahan Ottoman dan setelah kekalahan Ottoman, Mesir menjadi negara kerajaan meskipun secara de facto berada di bawah kendali Inggris. Kehidupan Mesir yang semula relijius, di mana para ulama banyak mendominasi kehidupan sosial dan politik, digantikan oleh kehidupan yang sekuler, disertai dengan kesenjangan ekonomi yang semakin melebar. Di masa inilah (tahun 1920-an) muncul gerakan dan pemikiran untuk mengembalikan agama ke dalam kehidupan sosial dan politik bangsa Mesir, yang dipimpin oleh dua faksi besar. Pertama, gerakan yang dipimpin oleh pemimpin spiritual dan akademik; dan kedua, gerakan yang dimotori oleh Ikhwan Al Muslimin yang didirikan oleh Hasan AI Banna pada tahun 1928. Gerakan IM pada awalnya bertujuan untuk mengubah Mesir menjadi negara yang menerapkan hukum Islam dan menyebarkan ideologinya melalui berbagai aktivitas ekonomi dan sosial. Namun gerakan ini kemudian berkembang seiring dengan masuknya pemikiran-pemikiran radikal yang dibawa oleh Sayid Qutb (Perliger, 2006).

IM pada masa ini berperan dalam gerakan pembebasan Mesir dari penjajahan Inggris, namun melalui aksi-aksi yang dalam terminologi modern dikategorikan sebagai terorisme. Aktivis-aktivis IM melakukan pembunuhan terhadap pejabatpejabat Inggris dan Mesir. Salah satu aksi terkenal adalah pembunuhan terhadap Amin Ottman Peha, petinggi Mesir, pada Januari 1945 dan Mahmud Nokrashi, Perdana Menteri Mesir pada Desember 1948. Dua bulan kemudian (Februari 1949), Al Banna tewas dibunuh oleh agen pemerintah. Pada masa yang sama, IM juga mengirimkan pasukan militan melawan Israel, terutama di perbatasan Mesir-Israel. Aksi ini, di mata sebagian besar umat Muslim Mesir adalah aksi 'jihad' membantu Palestina, sementara di mata Barat, aksi ini dikategorikan dalam terorisme.

Pada tahun 23 Juli 1953, militer Mesir melakukan kudeta kepada Raja Farouk dan Mesir menjadi republik dengan Gamal Abdul Nasser sebagai presiden. Pada era Raja Farouk maupun era Nasser, aktivitas IM dihadapi dengan tangan besi oleh rezim. Ribuan aktivis IM dipenjara dan organisasi ini dinyatakan terlarang.

'Auf (2017) membagi periodisasi terorisme di Mesir menjadi tiga bagian berdasarkan kepentingan politik dan lingkupnya, yaitu sebagai berikut. 


\section{Periode pertama (1940-1981)}

Pada masa ini, Ikhwan Al Muslimin membentuk milisi bersenjata AtTandzim Al-Khash. Aksi-aksi teror milisi ini ditujukan kepada pemerintah baik personal, instansi, dan properti- karena benturan visi dengan IM, di mana IM memandang pemerintah Mesir saat itu tidak Islami. Pemerintah menghadapi aksi-aksi IM dengan pembubaran organisasi tersebut, seperti yang dilakukan oleh Presiden Nasser dan Perdana Menteri An-Nuqrasyi Basya. Pada tahun 1981, aktivis IM membunuh Presiden Anwar Sadat pada tahun 1981 dengan alasan bahwa Sadat mengadakan perjanjian damai dengan Israel yang terjadi pada tahun 1978 (BBC, 2017). IM memandang perjanjian ini sebagai pengkhianatan Sadat, padahal sebelumnya Sadat pernah beraliansi dengan IM untuk melumpuhkan kekuatan kelompok kiri Mesir (Al-Khatib, 2012). Pada periode ini terlihat bahwa target serangan adalah politisi domestik.

\section{Periode kedua (1990-2006)}

Terorisme pada periode ini telah berkembang sedemikian rupa dan berbeda dari periode pertama, dilihat dari beberapa faktor:

1. Para aktor berasal dari kelompok-kelompok yang berbeda, meskipun umumnya pemikiran mereka berakar dari pemikiran jihad versi AI Qutb.

2. Memasuki tahun 1990-an, para jihadis Mesir'alumni' Afghanistan kembali ke Mesir. Mereka menjadi aktor baru di Mesir, membentuk banyak kelompok, dan membawa misi dan kepentingan yang berbeda dari aktor periode pertama.

3. Para aktor secara aktif melancarkan teror. Selain membunuh tokoh pemerintahan, seperti Ketua Parlemen Rafa'at Al-Mahgoub (1990), mereka lebih sering menyerang tempat pariwisata, baik turisnya (banyak yang berasal dari Israel), maupun fasilitas pariwisata. Target serangan pada tahun 1993 adalah Luxor, tahun 2004 adalah Hotel Hilton (Taba), dan tahun 2005 adalah kawasan wisata Sharm Al Sheikh.

Ditinjau dari target serangan, terlihat bahwa targetnya adalah pemerintah Mesir dan pelaku/pengguna industri turisme, yang dipandang sebagai representasi Barat di Timur Tengah dan pelindung kepentingan Israel di kawasan. Dengan demikian, dapat disimpulkan bahwa kepentingan politik di balik terorisme periode kedua ini adalah kepentingan politik dalam 
lingkup global, karena ditujukan sebagai reaksi atas penguasaan Amerika Serikat (Barat) di Timur Tengah sebagai kawasan Dunia Islam.

\section{Periode ketiga (2011-sekarang)}

Ledakan bom di gereja Al Qiddisun, gereja Kristen Koptik di Alexandria, disebutsebut sebagai aksi terorisme yang mengawali periode ini. Pihak pemerintah, baik personal maupun fasilitasnya, menjadi target utama penyerangan dan peledakan pada peride ini. Aktor utama periode ini adalah kelompok Al Tauhid wa Al Jihad yang berbasis di Provinsi Sinai Utara. Aksi-aksi teror tersebut semakin meningkat sejak kudeta militer terhadap Mursi. Selain kelompok Al Tauhid wa Al Jihad, di Sinai juga terdapat milisi Anshar Bayt AI Maqdis dan ISIS.

Terorisme periode ketiga ini diawali dengan eskalasi gerakan massa yang berdemo menentang Mubarak pada tahun 2011, sehingga konsentrasi aparat keamanan dan militer dipusatkan di ibu kota dan kota-kota besar lainnya. Akibatnya, wilayah Sinai Utara semakin terabaikan dan menjadi wilayah strategis bagi berkumpulnya kelompok-kelompok teroris Mesir yang telah ada sejak lama, seperti Al Takfir wa Al Hijra, Jays Al Islam, dan Jund Al Islam, serta kelompok-kelompok baru dari dalam negeri seperti Ajnad Misr, dan kelompok-kelompok dari luar negeri, seperti Anshar Bayt Al Maqdis, Kataib AI Furqan, Al Morabitoon, dan lain-lain.

Kondisi chaos di ibu kota pasca pelengseran Mursi memberikan peluang kepada kelompok-kelompok teror itu untuk masuk ke ibu kota. Dengan demikian, pada masa itu, fokus polisi dan militer Mesir terpecah antara menghadapi aksi-aksi protes para pendukung Mursi dan aksi-aksi teror dari berbagai kelompok yang berbasis di Sinai.

Selain itu, ada pula kelompok-kelompok teror baru yang tidak berbasis di Sinai, namun di sekitar Kairo, seperti Al 'Iqab AI Tsauri dan Harakah Al Muqawamah Al Sya'biyyah Mishr, yang biasa disebut sebagai ARPM (Allied Popular Resistance Movement). ARPM mendeklarasikan diri pada Januari tahun 2015, tepatnya ketika Mesir mengenang Revolusi 25 Januari. Kelompok ini tercatat telah melakukan aksi teror sebanyak lebih dari 130 kali. ARPM terbentuk setelah lengsernya Mursi pada Juli tahun 2013. Melalui akun Facebooknya yang telah diblokir sejak lama, mereka menyatakan bahwa instansi keamanan dan kepolisian menjadi target penyerangan mereka. Setelah itu, penyerangan dialihkan ke fasilitas-fasilitas korporasi internasional (TIMEP, 2017).

Rangkaian fenomena teror periode ketiga ini mengandung kepentingan politik yang bersifat dinamis. Penyerangan terhadap personal, instansi dan fasilitas militer 
dan pengadilan, menjadi perlawanan terhadap pemerintah (domestik). Kemudian penyerangan tempat-tempat umum, pusat-pusat ekonomi dan korporasi-korporasi internasional, menjadi simbol perlawanan terhadap hegemoni asing di Mesir. Sementara itu, penyerangan gereja, menjadi simbol perlawanan terhadap identitas keagamaan selain Islam. Aksi teror yang mereka lakukan dengan target dan kepentingan yang dinamis itu pada akhirnya akan berujung pada satu target utama yaitu pemerintah Mesir.

\section{Aspek Demografis Sinai Utara Sebagai Basis Kelompok Teroris}

Secara umum, Semenanjung Sinai merupakan wilayah yang istimewa dibanding wilayah lain bagi Mesir. Sinai, bersama kawasan Gurun Barat dan Gurun Timur merupakan produsen minyak utama Mesir, di samping TelukSuez. Pasca Perang ArabIsrael 1967, Sinai dikuasai Israel. Kemudian, pada 1973, Mesir melancarkan perang untuk merebut kembali semenanjung tersebut. Pada tahun 1978, ditandatangani perjanjian Mesir-Israel yang menyepakati bahwa Israel akan angkat kaki dari Sinai. Saat ini Sinai merupakan salah satu destinasi wisata utama di Mesir, antara lain berkat pantainya yang indah dan keberadaan gunung Sinai yang menjadi pusat peziarahan.

Provinsi Sinai Utara adalah salah satu provinsi yang terletak di timur laut Mesir yang meliputi bagian utara Semenanjung Sinai. Sebelah utaranya berbatasan dengan Provinsi Sinai Selatan, sebelah barat berbatasan dengan Port Sa'id, Ismailia, dan provinsi Suez, dan sebelah timur berbatasan dengan Jalur Gaza dan Israel. Ibukotanya adalah El-Arish yang dipimpin oleh seorang gubernur yang ditunjuk langsung oleh Presiden Mesir.

Akan tetapi saat ini Sinai, khususnya bagian utara yang paling banyak penduduknya, menjadi wilayah yang paling sensitif bagi Mesir. Wilayah ini menjadi sumber keputusan pemerintah dalam memberlakukan status darurat terorisme. Faktor yang membuat Sinai Utara menjadi magnet bagi kelompok-kelompok teroris terutama adalah kondisi ekonomi yang buruk, wilayahnya yang berbatasan langsung dengan Israel, dan komunikasi politik yang buruk antara Pemerintah Mesir dengan wilayah Sinai secara keseluruhan. Hal ini memicu disloyalitas penduduk Sinai terhadap pemerintah. Menurut Al-Markaz Al'Arabi (2012) disloyalitas Sinai tersebut mudah sekali terbentuk mengingat adanya beberapa hal berikut:

1. Wilayah Sinai Utara dulunya menyatu dengan Gaza, terutama sebagai jalur perdagangan dan interaksi sosial. Hal ini menyebabkan penduduk Sinai Utara secara emosional lebih dekat dengan Gaza daripada dengan Mesir. 
Kedekatan yang terbentuk sejak lama itu menjadikan Sinai Utara dan Gaza bagaikan satu wilayah, berinteraksi secara mendalam dan menciptakan ikatan keluarga.

2. Semenjak ditandatanganinya perjanjian damai Mesir-Israel, harapan penduduk Palestina kepada Mesir menjadi pupus. Bagi mereka, perdamaian ini sama artinya dengan mengakhiri pembelaan Mesir kepada Palestina. Sikap penduduk Palestina ini pun mempengaruhi cara pandang penduduk Sinai Utara kepada Pemerintah Mesir.

3. Gejolak keras di kawasan perbatasan di negara-negara yang dipimpin rezim militer biasa terjadi, sebagaimana terjadi pua di Mesir. Sikap represif pemerintah Mesir era Husni Mubarak, kemudian berlanjut pada era Jenderal Al Sisi telah menjatuhkan sangat banyak korban sipil di Sinai Utara dan sebagian dari korban itu memiliki ikatan kuat dengan penduduk Gaza.

4. Pemerintah Mesir juga bersikap diskriminatif di bidang birokrasi dan pembangunan di Sinai, sehinggai sulit bagi warga Sinai untuk memiliki sumber-sumber ekonomi dalam skala besar (Ali, 2013). Perekonomian Sinai Utara justru banyak ditopang oleh jalur perdagangan illegal melalui terowongan yang menghubungkan wilayah Sinai Utara dengan Gaza, namun kemudian pemerintah militer menghancurkan jalur ini.

Dengan keempat fakta diatas, kekecewaan menjadi faktor utama bagi terciptanya keadaan yang kacau-balau di Sinai Utara. Kendati faktor geopolitik dan ekonomi juga memiliki peran terkait lahirnya distabilitas keamanan Mesir, khususnya daerah Sinai Utara. Gerakan-gerakan separatisme yang muncul, terutama dengan potensi pembentukan Negara Islam Sinai Utara akan merongrong eksistensi Mesir sebagai negara berdaulat.

Untuk pembahasan selanjutnya, penulis akan lebih fokus pada gerakan terorisme di Sinai Utara khususnya Anshar Bayt AI Maqdis (ABM). Organisasi ini selama beberapa tahun terakhir ini, tepatnya pasca Arab Spring, telah menjadi organisasi teror yang paling aktif di Mesir khususnya wilayah Sinai. Pembahasan akan meninjau aspek sejarah, genealogi, dan pola rekrutmen ABM.

\section{Gerakan Terorisme Anshar Bayt Al Maqdis}

\section{Sejarah dan Genealogi Pemikiran Anshar Bayt Al Maqdis}

Berhembusnya badai Arab Spring di Mesir pada tahun 2011 silam telah menginspirasi seseorang bernama Tawfiq Muhammad Freij Ziada, mantan anggota 
dan pengikut kelompok jihad Tawhid wal Jihad. Tawfiq pun mendirikan suatu organisasi jihad yang kini dikenal dengan nama Anshar Jerusalem, namun seiring waktu, organisasi ini lebih dikenal dengan nama Anshar Bayt Al Maqdis (ABM) (TIMEP, 2017). Tawfiq juga diketahui pernah menjadi anggota Hamas, lalu kemudian keluar karena kecewa, kemudian menetap di Sinai. Lalu, dengan dukungan dari kelompok Tawhid wal Jihad, Tawfiq mendirikan ABM yang secara resmi diumumkan pada 25 Juni 2012. Kemudian beberapa kelompok jihad kecil ikut bergabung mendukung ABM (Moniquet dan Lhoussain, 2014).

ABM memiliki pusat kegiatan yang kuat dan solid di wilayah Sinai Utara, yang merupakan jalur strategis penghubung antara Mesir, Palestina, dan Israel. Dengan basis anggota yang terpusat di Sinai Utara, target operasi kelompok jihadis ini juga terfokus di Sinai, meskipun terkadang menarget pula daerah-daerah lainnya, seperti Kairo, Daqhalia, Sinai Selatan, Mathruh, Qayubia, New Valley, dan Ismailia. Jalur Gaza yang hingga hari ini masih menjadi arena konflik juga masuk dalam target operasi ABM (Moniquet dan Lhoussain, 2014).

Meskipun ABM adalah kelompok jihadis yang terbilang baru terbentuk di Mesir, namun jejak pemikiran Tawfiq terkait dengan jihad, terror, dan pendirian negara Islam dapat dilacak sejak jauh-jauh hari. Tawfiq diketahui pernah bersinggungan dengan para tokoh organisasi ekstrem yang sudah mapan lebih awal, seperti Tawhid wal Jihad, Jama'ah Islamiyyah, Al Qaeda, dan sebagainya (Global Security, 2017).

Keputusan Tawfiq untuk menjadikan wilayah Sinai sebagai basis organisasinya didasarkan pada pertimbangan bahwa Sinai utara adalah wilayah yang strategis dan jauh dari kontrol pemerintahan. Semenanjung Sinai merupakan daerah perbatasan yang sekaligus menjadi salah satu wilayah strategis bagi jalur perdagangan. Baik perdagangan legal maupun illegal (Al-Naggar, 2014).

ABM tampil sebagai bentuk kekecewaan Tawfiq Muhammad Freij Ziada terhadap sosio-politik rezim otoriter Mesir yang dianggap gagal dalam menuntaskan permasalahan negara baik ekonomi, sosial, dan politik. Sebenarnya ABM dapat dikatakan sebagai penerus tongkat estafet dari gerakan radikal terdahulu di Mesir, yang sejak tahun 1970-an telah bermunculan di Mesir. Gerakan tersebut diawali dari gerakan politik Islam yang lahir setelah menjalani proses panjang perdebatan intelektual, kekecewaan, dan keinginan untuk maju dan berubah.

Gerakan politik Islam atau dikenal juga dengan gerakan Islamis ini, menawarkan solusi bagi kebuntuan rezim berkuasa dalam mengatasi segala problematika kenegaraan, seperti korupsi, kemiskinan, dan kesewenang-wenangan penguasa. 
Solusi yang ditawarkan adalah kembali kepada nilai-nilai Islam karena Mesir adalah negara dengan penduduk mayoritas Muslim dan kehadiran ulama sangat dominan di tengah masyarakat. Kesadaran kolektif kaum Muslim di Mesir terhadap kondisi negeri mereka (yang dijajah oleh Inggris) menjadi salah satu daya tarik utama sehingga gerakan politik Islam dengan segera mendapatkan sambutan rakyat.

Salah satu gerakan kebangkitan Islam yang paling luas di Mesir adalah Ikhwan Al Muslimin (IM) yang didirikan Hassan AI Banna pada tahun 1928. Awalnya IM bukan merupakan gerakan politik, melainkan gerakan tarbiyah Islamiyyah (pendidikan Islam) yang bertujuan memberi pengajaran keislaman bagi masyarakat Mesir. Seiring dengan berjalannya waktu, IM bertransformasi menjadi gerakan politik dan awalnya mengambil posisi sebagai gerakan politik Islam non-ekstrem (Bayat, 2013) namun pasca wafatnya Al Banna, sebagian kalangan IM menerima pemikiran Sayyid Qutb yang lebih radikal dalam beroposisi kepada pemerintah. Sementara itu, Jama'ah Islamiyyah yang sejak awal pendiriannya adalah bertujuan politis dengan mendirikan negara bersistem Islam. Jama'ah Islamiyah didirikan pada tahun 1970 oleh Nageh yang kemudian berkembang pesat ketika dipimpin oleh Dr. Omar Abdel-Rahman, yang terkenal dengan masterpiece bukunya yang berjudul "Mawqif Al-Qur'an alaa Khusuhumih" yang menjadi rujukan dan legitimasi setiap aksi teror yang dilakukan oleh Jama'ah Islamiyyah.

Pemikiran radikal dengan makna berkeinginan untuk melakukan perubahan sistem pemerintahan secara radikal dengan menggunakan kekerasan (Muis, 2012:11) ini menyebar ke kalangan aktivisnya, dan mereka pun menyebar ke dalam berbagai organisasi lain yang muncul kemudian. Tawfiq Muhammad Freij Ziada, pendiri ABM, semula adalah anggota Jama'ah Islamiyyah. Kehadirannya dalam kontestasi politik Islam dapat dipandang sebagai respon atas kegagalan IM dalam mewujudkan negara bersistem Islam ala Sayyid Qutb. ABM sedikit banyak dapat dipandang sebagai merupakan produk 'perkawinan silang' Jama'ah Islamiyyah dan IM. Pada intinya, keduanya memiliki tujuan yang sama yaitu ingin menegakkan sebuah masyarakat yang adil dan makmur berlandaskan nilai-nilai Islam, karena sebagaimana dikatakan Mohammad Ayoob, Islam bukan hanya sekedar agama tetapi juga sebagai ideologi politik yang menjadi alat untuk mencapai tujuan politik yang terefleksi dari penggunaan simbol dan konsep Islamis di ranah publik (Gafur, 2014:6).

Semenanjung Sinai yang menjadi basis kekuatan ABM ini adalah suatu wilayah dengan persentase perekonomian rendah. Kemiskinan menjadi momok paling menakutkan bagi penduduk Sinai. Tercatat pada tahun 2008-2009 Sinai baru 
dapat keluar dari zona kemiskinan. Tetapi pada tahun 2010-2011 Sinai kembali mengalami penurunan perekonomian mengingat turunnya pendapatan pariwisata yang menjadi sumber utama pendapatan penduduk Sinai (Al Naggar, 2014). Bisa dikatakan, Sinai mengalami krisis pada saat terjadinya revolusi Mesir yang dikenal dengan Arab Spring.

Selain dari itu, seperti telah disinggung sebelumnya, Semenanjung Sinai adalah wilayah konflik antara Israel-Mesir. Israel pernah menduduki Sinai lalu pada 1978 Mesir-Israel menandatangani perjanjian Camp David untuk mengembalikan wilayah Sinai kepada Mesir. Perjanjian Camp David yang ditandatangani langsung oleh Anwar Sadat (dan PM Israel Menachem Begin) telah melukai hati rakyat Mesir, khususnya kaum Muslim pro-Palestina yang berharap Mesir menjadi negara super-power Arab dan berpihak kepada bangsa Arab-Palestina. Karena, dengan ditandatanganinya perjanjian tersebut artinya Mesir telah mengakui eksistensi Israel sebagai negara berdaulat. Pada tanggal 6 Oktober 1981, Presiden Anwar Sadat tewas ditembak; kelompok Islam Tandzim al-Khass (milisi bersenjata yang didirikan sebagian aktivis IM pada tahun 1940-an) mengaku bertanggung jawab (Djamaluddin, 2012).

Tewasnya Sadat memunculkan ketegangan politik di Mesir, terutama antara kelompok-kelompok Islam melawan rezim. Kemudian, Hosni Mubarak mengambil kendali pemerintahan Mesir. Pada awalnya, Mubarak menggandeng IM sebagai bentuk akomodasi pemerintahan terhadap tuntutan kaum oposisi. Politik Islam IM pada dasarnya lebih mengedepankan moderatisme dan melawan ekstremisme, sehingga mereka bersedia bekerja sama dengan pemerintah. Di bawah pimpinan Al Tilmisani, IM pun resmi berkoalisi dengan pemerintah pada tahun 1982. IM pun menjelma sebagai kekuatan politik baru dalam pemerintahan dan sebagian anggotanya mendapat jatah dalam struktural pemerintahan Mesir (Ranko, 2014:94).

Sementara itu, setelah tewasnya Presiden Sadat, terorisme di Mesir berkembang dengan lahirnya kelompok-kelompok teroris baru. Upaya rezim Mubarak merangkul IM sebenarnya merupakan strategi untuk meredam lahirnya kelompok-kelompok teror baru (Ranko, 2014:97). Namun, tujuan Mubarak tidak berhasil karena ideologi ekstrem a la Sayyid Qutb yang sudah terlanjur menyebar di tengah kelompokkelompok tersebut. Selanjutnya, seiring dengan semakin kuatnya posisi politik IM, rezim Mubarak berbalik memusuhi IM dan bahkan melakukan penangkapan terhadap para aktivisnya.

Revolusi Mesir Januari 2011 yang menggulingkan Mubarak dan disusul dengan pemilu, membawa IM ke puncak pemerintahan Mesir. Namun, hanya dalam setahun 
(2012-2013), Mursi pun digulingkan dalam kudeta militer. Mursi dan para tokoh IM dipenjara, dan para demonstran IM yang memprotes kudeta ditembaki oleh aparat. Kondisi ini memunculkan kekecewaan dan kemarahan para aktivis gerakan Islam dan kelompok-kelompok radikal. ABM dideklarasikan pada 25 Juni 2012 dan tidak lama setelah itu, rentetan aksi terorisme di Mesir kembali meruak. Di tengah kondisi negara yang mengalami pergolakan politik, ABM tampil dengan aksi teror yang sudah mereka persiapkan. Aksi teror tersebut, antara lain, dipicu kekecewaan mereka terhadap pelengseran Muhammad Mursi dari kursi kepresidenan (Gold 2014).

\section{Pola Rekrutmen Anggota Anshar Bayt Al Maqdis}

Sejak Revolusi Mesir 2011 melawan rezim Mubarak, terjadi ketidakstabilan keamanan di Semenanjung Sinai. Aksi-aksi protes warga Sinai kepada pemerintahan sering terjadi, diiringi dengan bermunculannya gerakan-gerakan kelompok ekstrem yang menjadikan Sinai sebagai basis kekuatan (Gold 2014). Setelah kudeta militer yang menggulingkan Mursi pada Juli 2013, ABM memperluas serangan mereka hingga ke ibukota negara, Kairo. Bom-bom dipasang di mobil-mobil dengan menarget pembunuhan pada pejabat pemerintahan. Para wisatawan yang berlibur di Sinai yang terkenal dengan pariwisanya juga menjadi target operasi teror. Operasi teror memang lebih difokuskan pada elemen asing yang berada di Mesir. Sebab gerakan ekstremis ini sangat menolak campur tangan asing di Mesir, seperti halnya Hassan al-Banna pendiri IM (Nasution, 2000).

Tidak hanya berhenti di situ, ABM dengan bermodal 2.000 anggota militan ini telah berhasil menarik perhatian organisasi teroris besar seperti AI Qaeda dan ISIS untuk melakukan merjer (Moniquet dan Lhoussain, 2014). Meski terhitung baru, anggota $A B M$ semakin hari semakin bertambah. Dengan menarget anggota dari masyarakat lokal Sinai, ABM memanfaatkan situasi dan kondisi yang terjadi di Sinai. Secara umum, masyarakat Sinai sangat kecewa dengan diskriminasi kebijakan ekonomi pemerintah pusat. Kekecewaan ini meluas dan mendarah-daging, sehingga bagi warga Sinai, pemerintah pusat adalah musuh mereka. Memanfaatkan situasi dan kondisi ini, ABM menjaring mereka untuk bersatu melawan pemerintah (Burgrova, 2016).

Ketika dukungan dari masyarakat lokal Sinai terhadap kelompok ekstrem menguat, pemerintah tidak segera tanggap. Perekonomian semakin memburuk tanpa solusi dari pemerintah, sementara kelompok ekstremis menawarkan jalan keluar yang lebih 'realistis' (Burgrova, 2016). Warga Sinai yang tergabung dengan 
ABM melakukan perdagangan illegal dengan kelompok ekstremis di luar Mesir, antara lain perdagangan senjata dan narkotika. Dengan demikian, faktor pemenuhan kebutuhan ekonomi dan doktrin jihad melawan rezim yang zalim dan kapitalis'asing', membuat mereka percaya diri untuk bergabung dengan ABM (AI Naggar, 2014).

Di sini terlihat adanya manuver delivering benefits yang dilakukan oleh ABM secara masif kepada masyarakat wilayah Sinai Utara, demi menjaga loyalitas anggota. Proses delivering benefits juga tampak dalam rekrutmen terhadap tangan kanan Tawfiq, antara lain Bedawi Nasif alias Muhammad Ali Afifi dan Muhammad alSaid Hassan Ibrahim al-Toukhi yang lebih dikenal dengan nama Abu Obayda. Nasif kemudian menjabat sebagai wakil organisasi dan di kemudian hari, Abu Obayda mengubah arah kelompok ABM ini menjadi organisasi yang kuat secara material, baik dalam lingkup regional maupun fungsional (TIMEP, 2017).

Bedawi Nasif awalnya berniat 'berjihad' di Irak dengan mengajak salah seorang temannya, Bakri Harun. Namun mereka terdampar di Yaman, hingga mereka dicekal dan dideportasi. Revolusi 2011 menjadi medan 'perjuangan' yang membawa Nasif kepada aksi-aksi dukungan terhadap kelompok-kelompok Islamis dalam melawan rezim Mubarak. Dalam suatu kesempatan, di tengah aksi demonstrasi di Tahrir Square, Kairo, Nasif bertemu dengan seseorang bernama Ahmad 'Asyusy (pemimpin Anshar As-Syari'ah untuk wilayah Mesir dan Afrika Utara) yang mendorongnya untuk mendirikan kelompok bersenjata dengan menjanjikan donasi. Nasif, melalui Bakri Harun, kemudian dipertemukan dengan Tawfiq. Nasif tidak hanya mendapatkan donasi besar, namun kepercayaan penuh dari Tawfiq. Nasif menjadi tangan kanan Tawfiq dan mobilisasi gerakan ABM di Sinai dipercayakan kepadanya. ${ }^{1}$ Sementara Abu Obayda (At-Toukhi) diberikan kepercayaan untuk memobilisasi pergerakan di Kairo (Farghili, 2016).

Selanjutnya, pada tahun 2014 ABM berafiliasi kepada ISIS, ditandai dengan bai'at (janji setia) dan mengubah namanya menjadi Wilayat Sinai. Proses bai'at ini menghasilkan produk negara Islam di wilayah Sinai. Keputusan ini diambil karena posisi ABM yang sulit bergerak karena adanya dominasi organisasi lain yang lebih kuat di wilayah tersebut, seperti AI-Qaeda dan ISIS. Disamping itu, terdapat faktor yang lebih mendesak, yakni banyaknya pemimpin senior ABM yang tewas terbunuh oleh pemerintah Mesir pada periode Maret-Oktober 2014 (Gartenstein-Ros, 2015). Serangan pemerintah Mesir ini adalah upaya untuk membalas aksi teror yang dilakukan ABM.

$1 \quad$ Kepercayaan ini membuat Nasif mampu merekrut anggota dan menancapkan pegngaruhnya di beberapa wilayah seperti Kairo, Qalyubiyah, Giza, Kafr Syeikh, Mansoura, distrik 6 Oktober, Qina, Bani Suwaif, dan Syarqiyya. 
Wilayat Sinai atau Anshar Al Dawla Al Islamiyyah fi Bayt Al Maqdis (Kelompok Partisan Negara Islam Bayt al-Maqdis) juga beranggotakan eks-aktivis Ikhwan Al Muslimin (IM). Kendati secara resmi IM pernah menyatakan tidak ada hubungan dengan $A B M$, tetapi banyak eks-IM yang akhirnya bergabung dengan ABM sebagai bentuk kekecewaan mereka terkait pelengseran Mursi pada tahun 2012 dan keinginan untuk membalas dendam. Lantas gerakan teror yang dilancarkan kelompok ABM dan kelompok ekstrem lainnya dikenal dengan gerakan Revolutionary Punisment (TIMEP, 2017):

Bergabungnya para anggota eks-IM ke ABM sangat menguntungkan bagi keduanya. Anggota eks-IM dapat menumpahkan kekecewaan yang mendalam pada rezim pemerintahan yang baru dengan melakukan radikalisasi atau aksi teror. Sementara itu, rekrutmen anggota eks-IM juga menjadi poin plus bagi ABM, dikarenakan dapat menarik lebih banyak perhatian publik. Lebih-lebih, dengan adanya kompetisi antarkelompok teror, semakin banyaknya rekrutmen anggota membuat $A B M$ semakin unggul di tengah kelompok ekstrim lainnya di Mesir.

Aksi-aksi teror yang dilakukan ABM juga memiliki pengaruh dalam upaya rekrutmen ini. Misalnya, upaya pembunuhan terhadap Menteri Dalam Negeri Mesir Mohammed Ibrahim pada 5 September 2013 serta pengeboman terhadap jaringan pipa gas alam pada 5 Februari 2011 dan 17 Januari 2014 (TIMEP, 2017) sebagai bentuk protes pada perekonomian Mesir, merupakan salah satu strategi ABM dalam mengorganisir pandangan publik tentang politik dan ekonomi rezim pemerintahan yang buruk. Aksi-aksi ini, ditambah dengan narasi-narasi agama (misalnya 'jihad' atau penegakan syariah) dapat dipandang sebagai bentuk promosi ABM sebagai kelompok teroris baru yang berguna untuk menarik perhatian publik sehingga memudahkan rekrutmen anggota baru.

\section{Kesimpulan}

Musim Semi Arab (Arab Spring) memang menjadi badai yang besar di Mesir. la tidak hanya menyebabkan pergolakan politik dan krisis ekonomi, namun juga peningkatan aksi-aksi terorisme dari kelompok-kelompok Islam ekstrim. Hubungan yang kuat antara revolusi politik Arab Spring di Mesir dengan meningkatnya aksi terorisme tidak hanya bertemu pada titik bahwa terorisme telah ada dalam sisi kelam dari perjalanan sejarah politik Mesir modern, namun juga adanya peluang yang terbuka akibat friksi politik yang tinggi antara rakyat sipil dengan rezim. 
Aksi-aksi terorisme tampak meningkat signifikan pasca dilengserkannya Muhammad Mursi dari jabatan Presiden. Kekecewaan massa pro-IM dan tindakan represif rezim membangkitkan sel-sel kelompok teror yang sejak lama telah muncul di Mesir. Salah satu di antara kelompok teror tersebut adalah Anshar Bayt Al Maqdis (ABM) yang memusatkan aktivitasnya di Semenanjung Sinai. ABM tidak hanya menjadi pionir meruaknya aksi-aksi teror pasca lengsernya Mursi, namun juga menjadi pintu bagi masuknya ISIS ke Mesir.

Tujuan kelompok-kelompok teror, termasuk $A B M$, adalah melawan perlakuan rezim militer Mesir. Di sini, faktor ekonomi merupakan salah satu penyebab utama orang-orang di kawasan Sinai utara yang mengalami diskriminasi ekonomi untuk bergabung dengan ABM. Faktor ekonomi dan narasi agama ('jihad') menjadi prose delivering benefits dalam merekrut anggota dan mempertahankan loyalitas anggota. Selain itu, ABM berafiliasi dengan organisasi teror yang lebih kuat, yaitu ISIS dan menetapkan tujuan untuk mendirikan Negara Islam. Dalam aksi-aksi terornya, ABM melakukan prinsip cost and benefit, yaitu mencari target-target yang menarik perhatian dan simpati publik (terutama publik yang menjadi sasaran rekrutmen), misalnya pejabat pemerintah dan orang-orang asing dengan memanfaatkan isu ketimpangan ekonomi.

Dengan demikian, upaya penanggulangan terorisme perlu dilakukan dua jalur. Pertama dengan memerangi kelompok-kelompok teroris tersebut secara tegas. Dan kedua, melakukan perbaikan kondisi ekonomi dan mengurangi ketimpangan ekonomi, serta menegakkan keadilan di tengah masyarakat.

\section{Daftar Pustaka}

'Ali, Abd Ar-Rahim. (2013). Saina ila Aina? Dalail wa Mu'syirat: Kharithah Al-Jama'ah AlJihadiyyah. [online] Dalam: http://www.acrseg.org/2306/bcrawl [23 Okt. 2017].

'Auf, Iman. (2017). Marahil Tathawwur Al-Irhab fi 80 'Aman. [online] Dalam: http:// www.almalnews.com/story/330557/19/-مراحل-تطور-الارهاب-ف380-[Diakses 10 Okt. 2017].

Aljazeera. (2017). Maa Hiya Khithatu al-Jazairi li Mukaafahati al-Irhaab. [online] Dalam: http://midan.aljazeera.net/reality/politics/2017/9/3/ ما-هي-خطة-الجزائر-لمكافحة [Diakses 17 Okt. 2017].

Al-Khatib, Muhammad Mahir Abd Al-Karim. (2012). Harakah Al-lkhwan Al-Muslimin; 'aradh wa naqd. Jordan: Al-Biruni. 
Allam, Rabha. (2017). Egypt: Three Generations of Terrorism. [online] Dalam: http:// www.english.ahram.org.eg/NewsContentP/4/137798/Opinion/Egypt-Threegeneration-of-terrorism-.aspx [Diakses 11 Okt. 2017].

Al-Markaz Al'Arabi li Al-Abhas wa Dirasat As-Syasat, (2012). Saina At-Taihah baina Ghiyab Ad-Daulah wa Al-Istitsmar As-Siyasi. Doha: Doha Institute.

Al-Naggar, Ahmed El-Sayed. (2014). Sinai: Forgotten Development and Present Terrorism.[online]Dalam:http://english.ahram.org.eg/NewsContentP/4/114451/ Opinion/Sinai-Forgotten-development-and-present-terrorism.aspx [Diakses 23 Nov. 2017].

As-Shawwani, Yusuf Muhammad. (2013). At-Tahddiyyat Al-Amniyyah li Ar-Rabi' Al- 'Arabi: Min Ishlah Al-Muassasat ila Muqarabah Jadidah li Al-Amn. Jurnal AlMustaqbal Al'Arabi, Vol 416, No. 2.

Bayat, Asef. (2013). Post-Islamism; The Changing Faces of Political Islam. New York: Oxford University Press.

BBC. (2017). 1979: Israel and Egypt Shake Hands on Peace Deal. [online] Dalam:http://www.bbc.co.uk/onthisday/hi/dates/stories/march/26/ newsid_2806000/2806245.stm [Diakses 19 Okt. 2017].

BHP UMY. (2016). Fenomena Pasca Arab Spring Beri Tantangan Baru. [online] Dalam: http://www.umy.ac.id/fenomena-pasca-arab-spring-beri-tantangan-baru.html [Diakses 12 Okt. 2017].

Burgrova, Helena. (2016). Insecurity in Sinai and Beyond; Wahy the Egyptian Counterterrorism Strategy is Failing. [online] Dalam: https://www.ssoar.info/ssoar/ bitstream/handle/document/54070/ssoar-2016-burgrova-Insecurity_in_Sinai_ and_Beyond.pdf?sequence=1 [Diakses 25 Des. 2017].

Conte, A. (2010). The Nature and Definition of Terrorism. [online] Dalam:http://www.springer.com/cda/content/document/cda_ downloaddocument/9 783642116070 - c1.pdf?SGWID=0-0 - 45 963468-p173954726 [Diakses 4 Feb. 2017].

Detik.com. (2011). Kronologi tumbangnya Rezim Mubarak. [online] Dalam: https:// news.detik.com/berita/1569889/kronologi-tumbangnya-rezim-mubarak [Diakses 12 Okt. 2017]. 
Djamaluddin, Dasman. (2012). Mission Accomplished; Mengawal Keberhasilan Perjanjian Camp David. Jakarta: PT. Penerbit Buku Kompas.

Farghili, Mahir. (2016). Muhammad Ali Al-Ism Al-Akhthar fi 'Alam Al-Jama'at AtTakfiriyyah. [online] Dalam: http://www.albawabhnews.com/1991145 [Diakses 15 Feb. 2018].

Gafur, Fakhry. (2014) Agama dan Demokrasi: Munculnya Politik Islam. Jurnal LIPI, Vol. 11 , No. 2.

Gartenstein-Ros, Daveed. (2015). ISIL'S International Expantion: What Does Anshar Baytal-Maqdis's Oath of Allegiance Mean?. [online] Dalam:https://warontherocks. com/2015/02/isils-international-expansion-what-does-ansar-bayt-al-maqdissoath-of-allegiance-mean/ [Diakses 22 Okt. 2017].

Global Security. (2017). Wilayat Sinai, Anshar Bayt Al Maqdis. [online] Dalam: https:// www.globalsecurity.org/military/world/para/abm.htm [Diakses 20 Okt. 2017].

Golbal Security.com, (2017). Wilayat Sinai, Anshar Bayt Al Maqdis. [online] Dalam: https://www.globalsecurity.org/military/world/para/abm.htm [Diakses 20 Sep. 2017].

Gold, Zack. (2014). Security in the Sinai: Present and Future. ICCT [online] Dalam: https://www.icct.nl/download/file/ICCT-Gold-Security-In-The-Sinai-March-2014. pdf [Diakses 25 Nov. 2017].

JPNN.com. (2013). Militer Mesir Paksa Presiden Mursi Lengser. [online] Dalam: https:// www.jpnn.com/news/militer-mesir-paksa-presiden-mursi-lengser [Diakses 11 Sep. 2017]

Moniquet, Claude dan Azergui, Lhoussain. (2014). Ansar Bayt al-Maqdis: The SinaiBasedgroup That Introduces It Self Into Israeli-Palestinian Conflict. [online] Dalam: http://www.esisc.org/upload/publications/briefings/ansar-bayt-al-maqdis-thesinai-basedgroup-that-introduces-itself-into-the-israeli-palestinian-conflict/ Ansar\%20Bayt\%20al-Maqdis\%20eng.pdf [Diakses 23 Okt. 2017].

Muis, Abdul. (2012). Pejuang Kemerdekaan adalah Teroris? Menjelaskan Pengertian Terorisme. Jurnal Paramadina, Vol. 9, No. 1.

Nasution, Khoiruddin. (2000). Gerakan Militan Islam Mesir dan Relevansinya dengan Politik Islam Indonesia; Studi Gerakan Ikhwan Al Muslimin. [online] Dalam: 
https://media.neliti.com/media/publications/89300-ID-gerakan-militan-islammesir-dan-relevans.pdf [Diakses 21 Nov. 2017].

Noon Post. (2014). Kharithatu al-Irhaab fii Tunisi. [online] Dalam: http://www. noonpost.org/content/1845 [Diakses 25 Okt. 2017].

Ozdamar, Ozgur. (2008). Theorizing Terrorist Behavior: Major Approaches and Their Characteristic. Jurnal Defence Against Terrorism Review, Vol 1, No. 2.

Perliger, Arie. (2006). Middle Eastern Terrorism. New York: Chelsea House.

Ranko, Annette. (2014). The Muslim Brotherhood and its Quest for Hegemony in Egypt; State-Discourse and Islamist Counter-Discourse. Hamburg: Springer VS.

Salenda, Kasjim. (2009). Terorisme dan Jihad dalam Perspektif Hukum Islam. Jakarta: Badan Litbang dan Diklat Departemen Agama RI.

Sky News Arabia. (2015). Libya Mirta' wa Milaadz li 'Unaashir al-Irhaab min Da’is wa al-Qaeda. [online] Dalam: http://www.skynewsarabia.com/web/article/798091/ [Diakses 27 Okt. 2017].

TIMEP (The Tahrir Institute for Middle East Policy). (2017). Revolutionary Punisment. Timep [online] Dalam: https://timep.org/esw/terror-groups/revolutionarypunishment/ [Diakses 23 Okt. 2017].

TIMEP (The Tahrir Institute for Middle East Policy). (2017). Wilayat Sinai. Timep [online] Dalam: https://timep.org/esw/terror-groups/wilayat-sinai/ [Diakses 21 Nov. 2017]. 